\title{
26. PHYSICAL PROPERTIES OF BASALTS FROM THE GALAPAGOS, LEG 70¹
}

\author{
Shun-ichiro Karato, Ocean Research Institute, 1-15-1, University of Tokyo, \\ Minamidai, Nakano-Ku, Tokyo 164, Japan²
}

\begin{abstract}
The physical properties of compressional and shear-wave velocity, bulk and grain density, porosity, electrical resistivity, and fluid permeability were measured on basalt samples cored from the Galapagos during Leg 70 .

These basalts are fresh and have higher density and sonic velocity than do those from older ocean crust. In addition, basalts from Sites 506, 507, and 508 (0.54 to $0.85 \mathrm{~m} . \mathrm{y}$.) have higher grain density and lower sonic velocity than do those from Site 510 (2.73 m.y.), which is probably the result of the higher $\mathrm{Fe}$ and $\mathrm{Ti}$ content of the former.

Mean fluid permeability was estimated to be about $1.3 \times 10^{-16} \mathrm{~cm}^{2}$ and the size of pores responsible for fluid flow was estimated by means of the relationships between permeability versus resistivity and permeability versus porosity to be about $0.03 \mu \mathrm{m}$ or more. The permeability of laboratory samples is much lower than the large-scale permeability $\left(10^{-11} \sim 10^{-10} \mathrm{~cm}^{2}\right)$ (Anderson et al., 1977; Karato and Becker, this volume), suggesting that hydrothermal circulation in basaltic layers may occur through larger-scale fissures whose width is about three orders of magnitude greater than that of laboratory samples.
\end{abstract}

\section{INTRODUCTION}

During Deep Sea Drilling Project (DSDP) Leg 70, drilling of basement rocks was attempted in the young oceanic crust near the Galapagos Spreading Center.

Although total penetration and recovery $(\sim 15 \%)$ were very low as a result of the occurrence of loose rubble and/or highly fractured rock at the sediment/basement interface, the basalts cored from this area are of special importance since geophysical and geochemical field studies show evidence of active hydrothermal circulation in this oceanic crust (e.g., Williams et al., 1974; Corliss et al., 1979; Green et al., 1981).

This chapter will present the results of measurements of physical properties of basalts from the Galapagos region and discuss their geophysical implications. Physical properties studied include: wet-bulk density, grain density, porosity, sonic velocity, electrical resistivity, and fluid permeability. All the measurements except porosity were made on seawater-saturated samples with a 2.5$\mathrm{cm}$ diameter and a 2- to 4- $\mathrm{cm}$ length. The results of the measurements and their mean values are given in Tables 1 and 2, respectively. Histograms of physical properties are given in Figure 1.

It should be noted that since the recovery was very low and since the measurements were made only on unfractured samples, the results reported here may not be representative of in situ physical properties. A good deal of the sections which were not recovered are probably broken and fractured rocks, possibly with lower densities.

\section{GRAVIMETRIC MEASUREMENTS}

The wet-bulk density of basalts was determined by weighing the samples in air to determine their mass and

\footnotetext{
${ }^{1}$ Honnorez, J., Von Herzen, R. P., et al., Init. Repts. DSDP, 70: Washington (U.S. Govt, Printing Office)

2 Present address: Research School of Earth Sciences, The Australian National University, Canberra 2600, Australia.
}

then suspending them in seawater to determine their volume. Water content was determined by weighing the samples, both when saturated with seawater and after drying at $110^{\circ} \mathrm{C}$ for 24 hours. Porosity and grain density were calculated from the wet-bulk density and water content data. The reproducibility of measurements was about $0.005 \mathrm{~g}$, thus the accuracy of density is about $0.1 \%$ and that of porosity is $\approx 1 \%$.

The wet-bulk density of 14 basalts ranges from 2.90 to $2.99 \mathrm{~g} / \mathrm{cm}^{3}$ with a mean of $2.94 \pm 0.02 \mathrm{~g} / \mathrm{cm}^{3}$, which is higher than average in DSDP basalts (Christensen and Salisbury, 1975).

The grain density of 14 basalts ranges from 2.97 to $3.06 \mathrm{~g} / \mathrm{cm}^{3}$ with a mean of $3.01 \pm 0.03 \mathrm{~g} / \mathrm{cm}^{3}$. Of particular interest is that the grain density of basalts from young Galapagos sites (Sites 506, 507, and 508, 0.54 to 0.85 m.y.) is significantly higher than the densities of basalts from Site 510 (2.73 m.y.) - values from Site 510 being comparable to or slightly larger than those of other "normal" basalts, such as at Sites 417 and 418 (Hamano, 1979) or Site 504 (Karato and Wilkens, in press; see Figs. 2 and 8). This high grain density of young Galapagos basalts may be attributed to their high Fe (and Ti) content (Hekinian et al., 1978). The difference in average grain density between young (Sites 506, 507, 508) and old (Site 510) Galapagos basalts is about $0.04 \pm 0.02 \mathrm{~g} /$ $\mathrm{cm}^{3}$ (see Figs. 1 and 2), corresponding to the difference in Fe content of about $5 \pm 3 \%$.

The porosity of 14 basalts ranges from 2.7 to $6.5 \%$ with a mean of $4.0 \pm 1.2 \%$. The porosity of Galapagos basalts is low compared to that of other areas (e.g., Site 417, Hamano, 1979; Site 332, Hyndman and Drury, 1976), suggesting their freshness.

\section{SONIC VELOCITY}

Compressive velocity $V_{p}$ (for 16 basalts) and shearwave velocity $V_{s}$ (for seven basalts) were measured under atmospheric pressure by a standard pulse transmission method using the mercury delay line at frequency of 1 
Table 1. Physical properties of basalts from the Galapagos.

\begin{tabular}{|c|c|c|c|c|c|c|c|c|}
\hline $\begin{array}{c}\text { Sample } \\
\text { (interval in } \mathrm{cm} \text { ) }\end{array}$ & $\begin{array}{c}\text { Wet-Bulk } \\
\text { Density } \\
\left(\mathrm{g} / \mathrm{cm}^{3}\right)\end{array}$ & $\begin{array}{c}\text { Grain } \\
\text { Density } \\
\left(\mathrm{g} / \mathrm{cm}^{3}\right)\end{array}$ & $\begin{array}{c}\text { Porosity } \\
(\%)\end{array}$ & $\begin{array}{l}\text { Compressional- } \\
\text { Wave Velocity } \\
(\mathrm{km} / \mathrm{s})\end{array}$ & $\begin{array}{c}\text { Shear-Wave } \\
\text { Velocity } \\
(\mathrm{km} / \mathrm{s})\end{array}$ & $\begin{array}{l}\text { Poisson's } \\
\text { Ratio }\end{array}$ & $\begin{array}{c}\text { Electrical } \\
\text { Resistivity } \\
(\mathrm{nm})\end{array}$ & $\begin{array}{c}\text { Fluid } \\
\text { Permeability } \\
\left(\mathrm{cm}^{2}\right)\end{array}$ \\
\hline $506 \mathrm{G}-2-1,86-88$ & 2.96 & 3.03 & 3.7 & 5.71 & 3.15 & 0.281 & 86.3 & - \\
\hline $507 \mathrm{~B}-1-1,18-20$ & 2.94 & 3.05 & 5.3 & 5.42 & - & - & 53.1 & - \\
\hline $507 \mathrm{~B}-1-1,43-45$ & 2.92 & 3.05 & 6.5 & 5.43 & - & - & 50.2 & $1.3 \times 10^{-15}$ \\
\hline $507 C-3-1,28-30$ & 2.99 & 3.06 & 3.1 & 5.70 & - & - & 58.5 & - \\
\hline $508 \mathrm{~B}-4-1,5-7$ & 2.90 & 3.00 & 5.7 & 5.60 & - & - & 119 & $1.0 \times 10^{-16}$ \\
\hline $508 \mathrm{C}, 1, \mathrm{CC}$ & - & - & - & 5.65 & - & - & 145 & - \\
\hline $510-8-2,100-102$ & - & - & - & 6.18 & - & - & 96.4 & - \\
\hline $510-9-1,24-26$ & 2.95 & 3.01 & 2.8 & 6.09 & 3.47 & 0.260 & 222 & $4.0 \times 10^{-17}$ \\
\hline $510-9-1,80-82$ & 2.93 & 2.99 & 3.2 & 5.51 & - & - & 106 & - \\
\hline $510-9-2,6-8$ & 2.93 & 3.00 & 3.9 & 6.11 & 3.29 & 0.296 & - & - \\
\hline $510-9-2,82-84$ & 2.91 & 2.97 & 3.0 & 6.27 & 3.41 & 0.290 & 108 & $9.5 \times 10^{-16}$ \\
\hline $510-9-2,94-96$ & 2.91 & 3.01 & 5.0 & 6.22 & 3.47 & 0.274 & 101 & - \\
\hline $510-9-2,135-137$ & 2.93 & 2.99 & 3.7 & 6.08 & - & - & 138 & $3.1 \times 10^{-16}$ \\
\hline $510-9-3,16-18$ & 2.94 & 3.00 & 3.7 & 5.90 & 3.21 & 0.290 & 79.7 & - \\
\hline $510-9-3,32-34$ & 2.96 & 3.02 & 2.7 & 5.95 & 3.25 & 0.287 & 46.0 & - \\
\hline $510-10-1,24-26$ & 2.94 & 3.01 & 3.6 & 5.77 & - & - & 111 & - \\
\hline
\end{tabular}

Table 2. Average physical properties of basalts (numbers in parentheses $=$ no. of measurements).

\begin{tabular}{|c|c|c|c|c|}
\hline $\begin{array}{l}\text { Physical } \\
\text { Properties }\end{array}$ & $\begin{array}{l}\text { Present } \\
\text { Results }\end{array}$ & $\begin{array}{c}\text { Hole 504B } \\
\text { Basalts }^{\mathrm{a}}\end{array}$ & $\begin{array}{l}\text { Leg } 37 \\
\text { Basalts }\end{array}$ & $\begin{array}{l}\text { Leg } 51-53 \\
\text { Basalts }\end{array}$ \\
\hline $\begin{array}{l}\text { et-Bulk Density } \\
\left(\mathrm{g} / \mathrm{cm}^{3}\right)\end{array}$ & $\begin{array}{c}2.94 \pm 0.02 \\
\text { (14) }\end{array}$ & $\begin{array}{c}2.93 \pm 0.05 \\
(64)\end{array}$ & $\begin{array}{l}2.80 \pm 0.08 \\
\text { (101) }\end{array}$ & $\begin{array}{c}2.79 \pm 0.13 \\
(185)\end{array}$ \\
\hline $\begin{array}{l}\text { Grain Density } \\
\left(\mathrm{g} / \mathrm{cm}^{3}\right)\end{array}$ & $\begin{array}{l}3.01 \pm 0.03 \\
\text { (14) }\end{array}$ & $\begin{array}{l}3.01 \pm 0.03 \\
(64)\end{array}$ & $\begin{array}{l}2.95 \pm 0.05 \\
(85)\end{array}$ & $2.91=$ \\
\hline Porosity ( & $\begin{array}{r}4.0 \pm \\
(14)\end{array}$ & $\begin{array}{l}4.1 \pm \\
(64\end{array}$ & $\begin{aligned} 7.8 & \pm 4.1 \\
& (85)\end{aligned}$ & $\begin{array}{c}8.4 \pm 5.5 \\
(104)\end{array}$ \\
\hline $\begin{array}{l}\text { Compressional-Wave } \\
\text { Velocity }(\mathrm{km} / \mathrm{s})\end{array}$ & $\begin{array}{c}5.85 \pm 0.29 \\
(16)\end{array}$ & $\begin{array}{c}5.99 \pm 0.31 \\
(55)\end{array}$ & $\begin{array}{l}5.94 \pm 0.34^{d} \\
\text { (79) }\end{array}$ & $\begin{array}{c}5.48 \pm 0.48 \\
(189)\end{array}$ \\
\hline $\begin{array}{l}\text { Shear-Wave Velocity } \\
(\mathrm{km} / \mathrm{s})\end{array}$ & $\begin{array}{c}3.32 \pm 0.13 \\
\text { (7) }\end{array}$ & - & $\begin{array}{l}3.27 \pm 0.34^{\mathrm{d}} \\
(37)\end{array}$ & $\begin{array}{c}3.10 \pm 0.21 \\
(65)\end{array}$ \\
\hline Poisson's Ratio & $0.283 \pm 0.012$ & - & $\begin{array}{c}0.295 \pm 0.011^{\mathrm{d}} \\
\text { (37) }\end{array}$ & $\begin{array}{c}0.282 \pm 0.011 \\
(65)\end{array}$ \\
\hline $\begin{array}{l}\text { Electrical Resistivity } \\
(\Omega \mathrm{m})^{\mathrm{e}}\end{array}$ & $\begin{array}{l}84.9 \\
(15)\end{array}$ & & $\begin{array}{l}220 \\
(87)\end{array}$ & $\begin{array}{l}120 \\
(48)\end{array}$ \\
\hline Permeability $\left(\mathrm{cm}^{2}\right)^{\mathrm{e}}$ & $1.3 \times \underbrace{10^{-16}}_{(5)}$ & $\begin{array}{c}4.7 \times 10^{-16} \\
(13)\end{array}$ & - & $\begin{array}{c}1.1 \times 10^{-16} \\
(16)\end{array}$ \\
\hline
\end{tabular}

${ }^{a}$ Karato (in press).

b Hyndman and Drury (1976).

c Hamano (1979).

d Measured at $0.5 \mathrm{~kb}$

e Geometric mean.

f Air permeability.
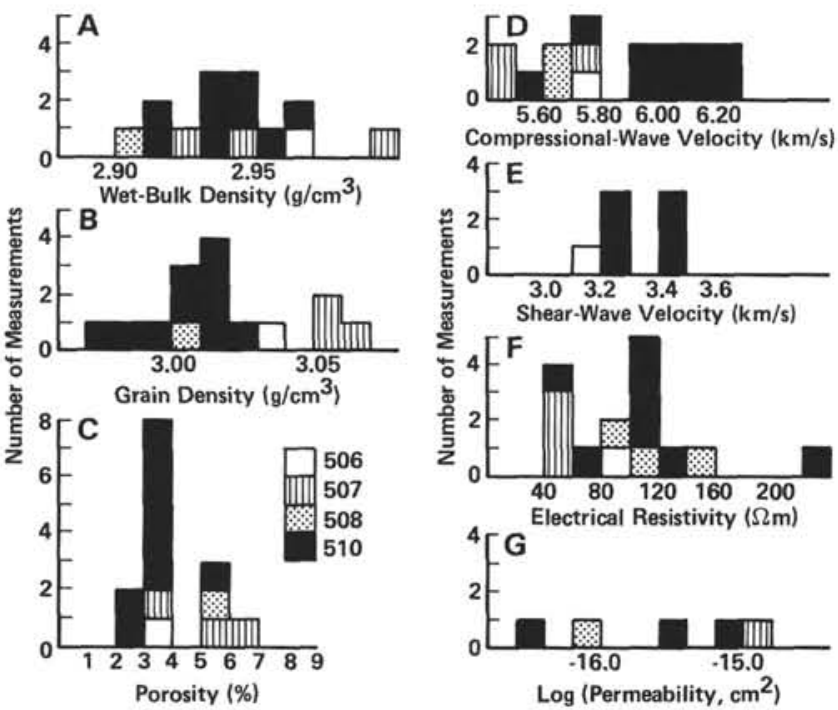

Figure 1. Histograms of physical properties.

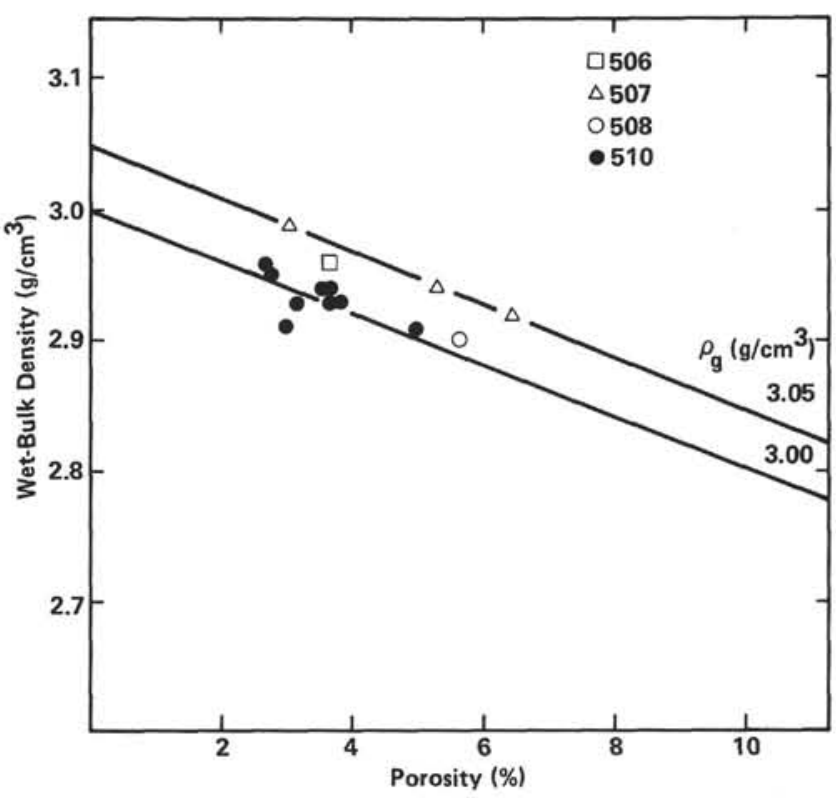

Figure 2. Wet-bulk density versus porosity for constant grain density of 3.05 and $3.00 \mathrm{~g} / \mathrm{cm}^{3}$.

$\mathrm{MHz}$ (for $V_{p}$ ) and $500 \mathrm{kHz}$ (for $V_{s}$ ). The accuracy of the measurements, found to be about $1 \%$ and $2 \%$ for $V_{p}$ and $V_{s}$, respectively, was checked by repeating them several times and by using aluminum standards.

Compressional-wave velocity ranges from 5.42 to 6.27 $\mathrm{km} / \mathrm{s}$, with a mean of $5.85 \pm 0.29 \mathrm{~km} / \mathrm{s}$. This mean value of $V_{p}$ is higher than that of average DSDP basalts (Christensen and Salisbury, 1975) and basalts from 100 m.y. old Atlantic floor (Holes 417D and 418A; Hamano, 1979). Such a high average value of sonic velocity is common for young oceanic basalts (e.g., Hyndman and Drury, 1976; Kirkpatrick, 1979) and may reflect the freshness of young oceanic basalts.

More specifically, it is notable that the sonic velocity of young Galapagos basalts is significantly lower than that of old Galapagos basalts (Fig. 1), although the wetbulk densities are similar. The wet-bulk density versus $V_{p}$ relationship shown in Figure 3 clearly demonstrates 


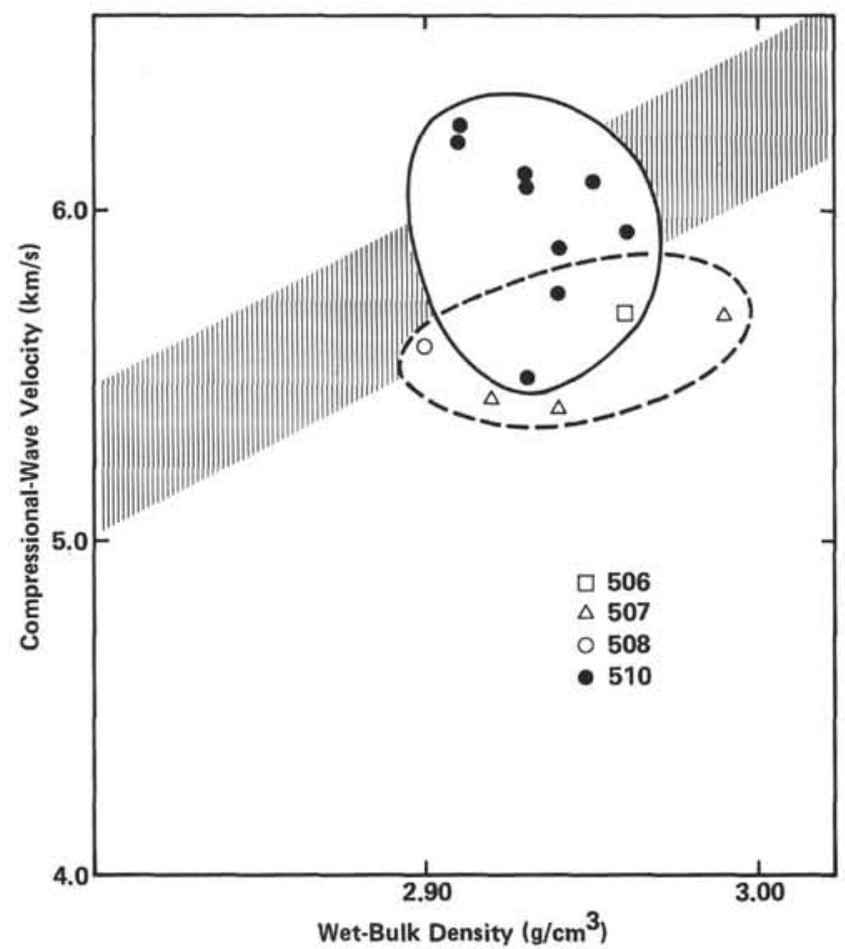

Figure 3. Relationship between compressional-wave velocity and wetbulk density. Shaded area shows the range of velocity versus density relation for basalts from Hole 504B (Karato, in press).

this difference. Most of the data points for old Galapagos basalts fall within the range of density versus $V_{p}$ plots for Site 504 basalts (Karato, in press), which is shown by the shaded area in Figure 3. In addition, they are nearly equivalent to basalts from other sites (e.g., Site 417 and 418; Hamano, 1979). However, the data points of young Galapagos basalts fall significantly below this trend. This difference in the density versus velocity plots between young and old Galapagos basalts may be attributed to their difference in bulk chemistry. Hekinian et al. (1978) show that basalts from young Galapagos have unusually high $\mathrm{Fe}$ and $\mathrm{Ti}$ content. In general, rocks with higher $\mathrm{Fe}$ and $\mathrm{Ti}$ content have lower sonic velocity compared at equal densities (Birch, 1961). If the relationship between velocity, density, and mean atomic number of rocks (Birch's law) is applicable, one can estimate the difference in mean atomic number between young and old Galapagos basalts at about $0.5 \pm$ 0.2 , which correspond to the difference in $\mathrm{Fe}$ (and $\mathrm{Ti}$ ) content of about $4 \pm 2 \%$. This is in good agreement with grain density data.

The shear-wave velocity of seven basalts ranges from 3.15 to $3.47 \mathrm{~km} / \mathrm{s}$ with a mean of $3.32 \pm 0.13 \mathrm{~km} / \mathrm{s}$. Poisson's ratio, calculated from $V_{p}$ and $V_{s}$, ranges from 0.260 to 0.296 with a mean of $0.283 \pm 0.012$.

\section{ELECTRICAL RESISTIVITY}

The electrical resistivity of 15 basalts was measured at laboratory temperatures $\left(22-25^{\circ} \mathrm{C}\right)$ and atmospheric pressure using a $1 \mathrm{kHz}$ AC bridge. The Pt electrodes were attached to both ends of the cylindrical samples and a rubber jacket wrapped around the sample surface to prevent water evaporation during measurements. The resistivity of the samples can be determined to within $1 \%$ error, but the reproducibility is only about $10 \%$. Electrical resistivity ranges from 46.0 to $222 \Omega \mathrm{m}$ with a geometric mean of $84.9 \Omega \mathrm{m}$. A histogram of electrical resistivity is shown in Figure 1, and electrical resistivity is plotted against porosity in Figure 4.

Applying Archie's law (Archie, 1942),

$$
\varrho / \varrho_{\mathrm{f}}=\phi^{-q}
$$

where $\varrho$ is the resistivity of (sea) water saturated rock, $\varrho_{f}$ is the resistivity of (sea) water $(=0.2 \Omega \mathrm{m}), \phi$ is the porosity, and the exponent $q$, a constant, is estimated at $1.91 \pm 0.22$ (Fig. 4). In Archie's law $q$ may represent the connectivity of pores (Shankland and Waff, 1975). When the connectivity does not increase with porosity, as could be expected for very flat pore shape, $q$ is equal to unity. If the connectivity of pores increases with porosity, $q$ is larger than unity, and $q$ is equal to 2 for cylindrical pore shapes (Brace et al., 1965; Shankland and Waff, 1975). The value of $q(=1.91 \pm 0.22)$, therefore, suggests that the pores which are responsible for carrying electric charge have nearly equidimensional shape, i.e., cylindrical.

The foregoing discussion, however, depends on the nature of porosity. Though only connected pores are responsible for electrical resistivity, the values estimated

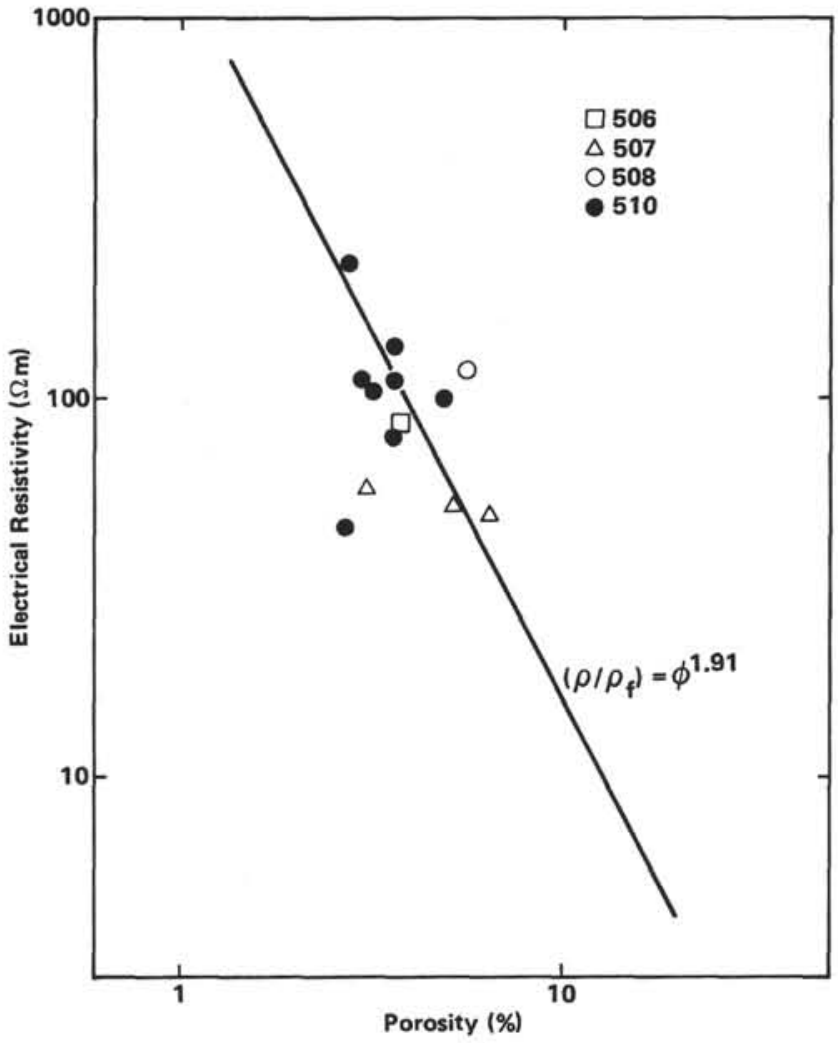

Figure 4. Relationship between electrical resistivity and porosity. (Solid line represents Archie's law. $\varrho=$ resistivity, $\varrho_{\mathrm{f}}=$ fluid resistivity, and $\phi=$ porosity.) 
by the present method may include isolated pores. Thus, the measured values represent only the upper limit of the porosity due to connected pores. The data points in Figure 4 should, therefore, be shifted to the left if the abscissa represents the porosity due to connected pores; in this case $q$ may be smaller than that estimated.

Electrical resistivity was measured for two typical samples (fresh basalt, 507B-1-1, 43-45 cm and a relatively weathered basalt, $510-9-2,82-84 \mathrm{~cm}$ ) at temperatures ranging from laboratory temperature to about $80^{\circ} \mathrm{C}$. Measurements were made while temperatures were both increasing and decreasing, and no hysteresis was found. Activation energy of electrical conduction, E*, was estimated by assuming Arrhenius's relation. The results are shown in Figure 5. The activation energy of fresh basalt is close to that of seawater. On the other hand, that of weathered basalt is larger than that of seawater, probably because of the effects of clay minerals on electrical conductivity. At any rate, these activation energies are much smaller than that of dry basalts (Hyndman et al., 1979), suggesting that conduction through pore fluids (with some interactions with clay minerals) is a major avenue for electrical conduction in oceanic basalts.

\section{FLUID PERMEABILITY}

The permeability of seawater through five basalt samples was measured by a standard, constant head-pressure method at laboratory temperatures. A schematic diagram of the permeability measurement equipment is shown in Karato (in press). Measurements of permeability were made by applying a constant head pressure $P$ of about 70 bars (kept constant to within $0.5 \%$ during a run) under about 150 bars confining pressure, and by measuring the volume of seawater, $Q$, passed through a

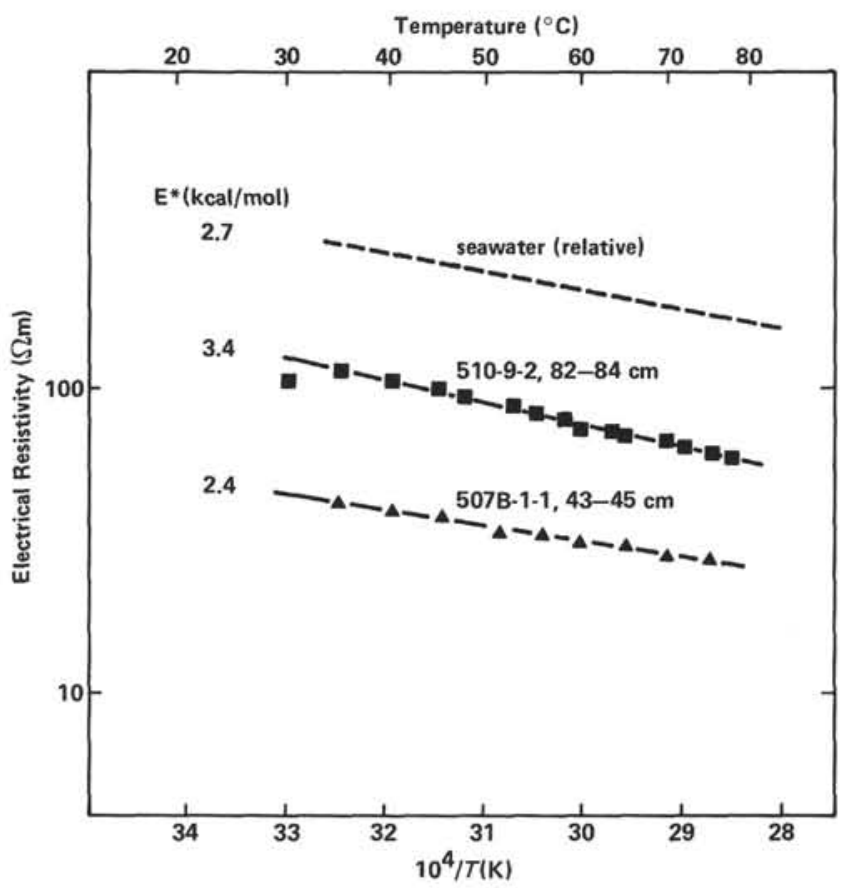

Figure 5. Variation of electrical resistivity with temperature. sample in a given time interval $\Delta t$. Permeability, $k$, of the sample was calculated by Darcy's law as,

$$
k=\frac{Q}{\Delta t} \frac{\eta}{p} \frac{L}{A}
$$

where $\eta$ is the viscosity of seawater ( $=0.01$ poise), $L$ is the length of the sample, and $A$ is its cross-sectional area. Measurements of seawater volume flux were made for three time intervals, and the mean of these values was used for the permeability calculation. Further, the validity of Darcy's law (i.e., the linearity of the relationship between $P$ and $Q$ ) was checked by measuring the flow rate at several values of head pressure (see Karato, in press. The accuracy of each measurement is about $20 \%$, and the validity of Darcy's law was confirmed within this experimental error. However, reproducibility was only about $50 \%$ or less. Plugging of pores by small particles may cause large fluctuations which result in large errors, since the dimensions of the pores are much less than the mesh dimensions of the line filter.

The permeability of basalts ranges from $4.0 \times 10^{-17}$ to $1.3 \times 10^{-15} \mathrm{~cm}^{2}$ with a geometric mean of $1.3 \times 10^{-16}$ $\mathrm{cm}^{2}$. These values are comparable to those of fresh basalts from Hole 418A (Johnson, 1979), but significantly lower than the bulk permeability of ocean crust in this area $\left(10^{-11}\right.$ to $\left.10^{-10} \mathrm{~cm}^{2}\right)$ estimated from heat flow data and the hydraulic impedance of the sediment layers (Anderson et al., 1977; Karato and Becker, this volume).

Permeability is plotted against porosity in Figure 6 and against electrical resistivity in Figure 7. Although the amount of data is too small to discuss their correlation, it may be interesting to interpret these data by developing a microscopic model of pores from which to estimate pore dimension.

Hubbert (1956; see also Brace, 1977) showed the relation between electrical resistivity and the permeability of a fluid-saturated rock to be,

$$
k=\left(m^{2} / k_{0}\right) F^{-2} \phi^{-1}
$$

where $k$ is permeability, $k_{0}$ is a shape factor which can vary between 2 and 3 , and $\phi$ is porosity. Here $m$ is the hydraulic radius, which is the volume of the interconnected pores divided by their surface area. $F$ is the formation factor, the ratio of the resistivity of fluid-saturated rock to that of fluid alone.

Combining equations (1) and (3), we have

$$
\begin{aligned}
k & =\left(m^{2} / k_{0}\right) \phi^{2 q-1} \\
& =\left(m^{2} / k_{0}\right) \phi^{2.82}
\end{aligned}
$$

or

$$
\begin{aligned}
k & =\left(m^{2} / k_{0}\right)\left(\varrho / \varrho_{\mathrm{f}}\right)^{\frac{1-2 q}{q}} \\
& =\left(m^{2} / k_{0}\right)\left(\varrho / \varrho_{\mathrm{f}}\right)^{-1.48}
\end{aligned}
$$




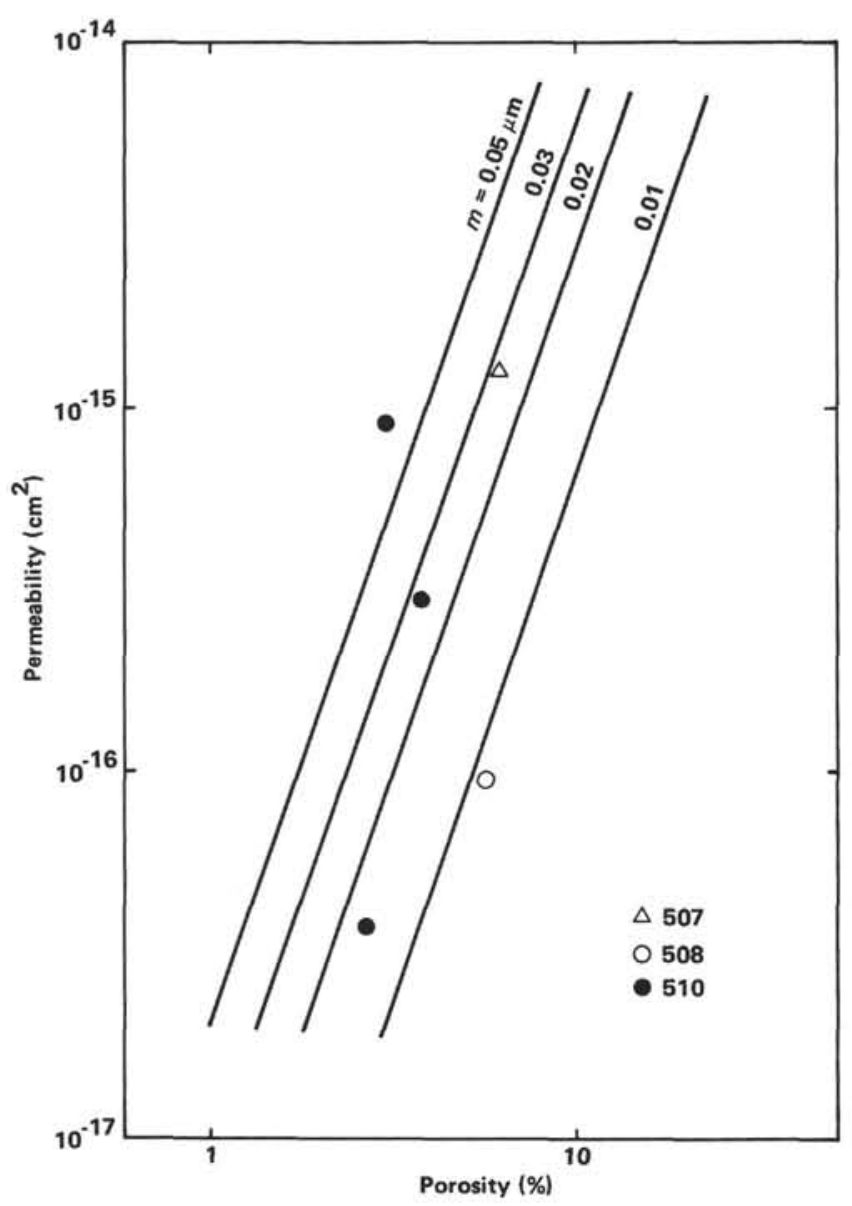

Figure 6. Relationship between permeability and porosity. Solid lines show theoretical relations ( $\left.4^{\prime}\right)$ with several values of $m$ (hydraulic radius).

Relations ( $\left.4^{\prime}\right)$ and $\left(5^{\prime}\right)$ for various values of $m$ (for $k_{0}=$ $2.5)$ are shown in Figures 6 and 7. From these, we can estimate the hydraulic radius ( $\sim$ pore size) at 0.009 to 0.07 $\mu \mathrm{m}$ from the $k$ versus $\phi$ relation and at 0.02 to $0.05 \mu \mathrm{m}$ from the $k$ versus $\varrho$ relation, respectively. Pore size thus estimated is an average value. Petrographic observation of thin sections shows that there are many pores whose size is larger than $10 \mu \mathrm{m}$. The results, therefore, suggest that these large pores may be isolated or connected by small size pores, and the latter may determine the bulk permeability.

Further, as mentioned earlier, porosity estimated by the present method may include that resulting from isolated pores. Since only connected pores are responsible for fluid flow, the estimate of hydraulic radius should be made by plotting permeability versus porosity due to connected pores. In other words, the data points in Figure 6 should be shifted to the left to some extent. Therefore, the value of $m$ estimated by this method may be the lower limit of the actual value.

The sensitivity of fluid permeability to pore size (see equation 3 ) suggests that the large difference between the permeability of laboratory samples and that of ocean crust may be attributed to the difference in hydraulic radius (difference in porosity may be less than one order

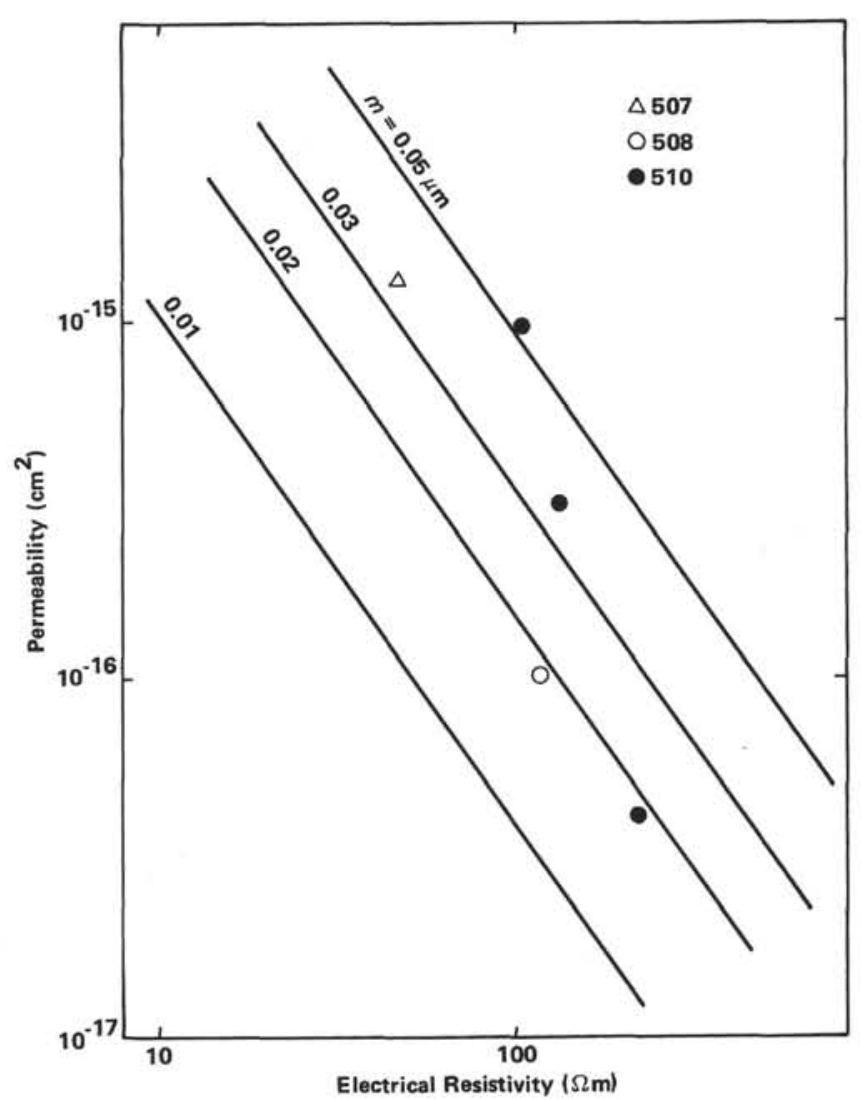

Figure 7. Relationship between permeability and electrical resistivity. Solid lines show theoretical relations ( $\left.5^{\prime}\right)$ with several values of $m$ (hydraulic radius).

of magnitude). If the relation $4^{\prime}$ can be used for large scale flow, we could estimated the hydraulic radius as being of the order of $10 \mu \mathrm{m}$ for $\phi \cong 0.1$ and $k \cong 10^{-10}$ $\mathrm{cm}^{2}$. Hydrothermal circulation may occur mainly through these relatively large scale fissures, and the majority of basement rocks can react with hydrothermal water only by diffusion of chemical species through pores.

\section{ACKNOWLEDGMENTS}

I wish to express my appreciation for the opportunity to participate on Leg 70 of the Deep Sea Drilling Project. I thank Jim Pine for the gravimetric measurements, Rikio Numajiri and Hiroshi Morishima for their assistance in the permeability measurement, Yozo Hamano for discussion, Naoyuki Fujii and Kei Kurita for reviewing the manuscript, and Sayuri Washida for typing the manuscript.

\section{REFERENCES}

Anderson, R. N., Langseth, M. G., and Sclater, J. G., 1977. The mechanism of heat transfer through the floor of the Indian Ocean. J. Geophys. Res., 82:3391-3409.

Archie, G. E., 1942. The electrical resistivity log as an aid in determining reservoir characteristics. J. Pet. Technol., 5:1-8.

Birch, F., 1961. The velocity of compressional waves in rocks to 10 Kbar, 2. J. Geophys. Res., 66:2199-2224.

Brace, W. F., 1977. Permeability from resistivity and pore shape. $J$. Geophys. Res., 82:3343-3349.

Brace, W. F., Orange, A. S., and Madden, T. R., 1965. The effect of pressure on the electrical resistivity of water-saturated crystalline rocks. J. Geophys. Res., 70:5669-5678. 
Christensen, N. I., and Salisbury, M. H., 1975. Structure and constitution of the lower oceanic crust. Rev. Geophys. Space Phys., 13: 57-86.

Corliss, J. B., Dymond, J., Gordon, L. I., Edmond, J. M., Von Herzen, R. P., Ballard, R. D., Green, K., Williams, D., Bainbridge, A., Crane, K., and Van Andel, Tj. H., 1979. Submarine thermal springs on the Galapagos Rift. Science, 203:1073-1083.

Green, K., Von Herzen, R. P., and Williams, D. L., 1981. The Galapagos Spreading Center at $86^{\circ} \mathrm{W}$ : A detailed geothermal field study. J. Geophys. Res., 86:979-986.

Hamano, Y., 1980. Physical properties of basalts from Holes 417D and 418A. In Donnelly, T., Francheteau, J., Bryan, W., Robinson, P., Flower, M., Salisbury, M., et al., Init. Repts. DSDP, 51, 52, 53, Pt. 2: Washington (U.S. Govt. Printing Office), 1457-1466.

Hekinian, R., Rosendahl, B. R., Cronan, D. S., Dmitriev, Y., Fodor, R. V., Goll, R. M., Hoffert, M., Humphris, S. E., Mattey, D. P., Natland, J., Petersen, N., Roggenthen, W., Schrader, E. L., Srivastava, R. K., and Warren, N., 1978. Hydrothermal deposits and associated basement rocks from the Galapagos Spreading Center. Oceanol. Acta, 1:473-482.

Hubbert, M. K., 1956. Darcy's law and the field equations of the flow of underground fluids. Trans. AIME, 207:222-239.

Hyndman, R. D., Christensen, N. I., and Drury, M. J., 1979. Seismic velocities, densities, electrical resistivities, porosities, and thermal conductivities of core samples from boreholes into the islands of Bermuda and the Azores. In Talwani, M., Harrison, C. G., and Hayes, D. E. (Eds.), Deep Drilling Results in the Atlantic Ocean:
Ocean Crust: Washington, D.C. (American Geophysical Union), pp. 94-112.

Hyndman, R. D., and Drury, M. J., 1976. The physical properties of oceanic basement rocks from deep drilling on the Mid-Atlantic Ridge. J. Geophys. Res., 81:4042-4052.

Johnson, D. M., 1980. Fluid permeability of oceanic basalts. In Donnelly, T., Francheteau, J., Bryan, W., Robinson, P., Flower, M., Salisbury, M., et al., Init. Repts. DSDP 51, 52, 53, Pt. 2: Washington (U.S. Govt. Printing Office), 1473-1477.

Karato, S., in press. Physical properties of basalts from Hole 504B, Costa Rica Rift, Legs 69 and 70. In Langseth, M. G., Cann, J. R., et al., Init. Repts. DSDP, 69: Washington (U.S. Govt. Printing Office).

Karato, S., and Wilkens, R. H., in press. Shipboard physical properties measurements of basalts from Costa Rica Rift, Leg 69. In Langseth, M. G., Cann, J. R., et al., Init. Repts. DSDP, 69: Washington (U.S. Govt. Printing Office).

Kirkpatrick, R. J., 1979. The physical state of the oceanic crust: Results of downhole geophysical logging in the Mid-Atlantic Ridge at $23^{\circ}$ N. J. Geophys. Res., 84:178-188.

Shankland, T. J., and Waff, H. S., 1975. Conductivity in fluid-bearing rocks. J. Geophys. Res., 79:4863-4868.

Williams, D. L., Von Herzen, R. P., Sclater, J. G., and Anderson, R. N., 1974. The Galapagos Spreading Centre: Lithospheric cooling and hydrothermal circulation. Geophys. J. R. Astron. Soc., 38: 587-608. 